\title{
PENGARUH TEKNIK PEMBELAJARAN MIND MAPPING TERHADAP KEMAMPUAN MENULIS NARASI SISWA KELAS V DI SDN KECAMATAN SUKASARI BANDUNG
}

\author{
Feby Inggriyani \\ PGSD FKIP Universitas Pasundan \\ Email : febyinggriyani@unpas.ac.id
}

\begin{abstract}
ABSTRAK
Masalah dalam penelitian ini adalah siswa kelas V di SDN Kecamatan Sukasari Bandung tahun akademik 2013/2014 mengalami kesulitan jika diberikan tugas untuk menulis narasi. Penelitian ini bertujuan untuk mengetahui pengaruh teknik pembelajaran mind mapping terhadap kemampuan menulis narasi siswa kelas V SD di Kecamatan Sukasari Kota Bandung. Metode yang digunakan dalam penelitian ini adalah eksperimen model two group post-test design Kemampuan menulis narasi pada siswa yang belajar dengan menggunakan teknik mind mapping memiliki nilai rata-rata 81,95 dengan nilai tertinggi adalah 92 dan terendah 68. Kemampuan menulis narasi pada siswa yang belajar dengan teknik konvensional memiliki nilai rata-rata 76,2 dengan nilai tertinggi 86 dan terendah 67. Hasil perhitungan uji hipotesis diperoleh bahwa $t_{\text {hitung }}>t_{\text {tabel }}$ pada taraf signifikan 0,05 (95\%) dengan ketentuan apabila thitung lebih besar dari tabel yakni 2,527>1,729 berarti Ho ditolak sebaliknya Ha diterima. Dengan demikian, teknik pembelajaran mind mapping berpengaruh terhadap kemampuan menulis narasi siswa kelas V SDN 4 Sukarasa Kota Bandung Tahun 2014.
\end{abstract}

Kata Kunci : kemampuan menulis, menulis narasi, teknik pembelajaran mind mapping

\begin{abstract}
The problem in this research is a fifth grade students at SDN District Sukasari Bandung academic year 2013/2014 in trouble if given the assignment to write a narrative. This study aims to determine the effect of learning techniques of mind mapping to the ability to write narrative fifth grade elementary school students in District Sukasari Bandung. The method used in this study is a model experimental two group post-test design. Narrative writing skills in students who learn using mind mapping technique has an average value of 81.95 with a highest score was 92 and the lowest 68. While the ability to write narratives on students who studied with conventional techniques have an average value of 76.2 with a value the highest score 86 and the lowest 67. The calculation result shows that the hypothesis test thitung > ttable at significant level of 0.05 (95\%) provided that if thitung greater than ttable namely 2.527> 1.729 means that Ho refused otherwise Ha accepted. Thus, learning techniques of mind mapping affect the ability to write narrative fifth grade students of SDN 4 Sukarasa Bandung 2014.
\end{abstract}

Keywords: writing ability, writing narration, learning technique of mind mapping

\section{PENDAHULUAN}

Bahasa merupakan aspek yang berperan penting dalam kehidupan manusia. Tanpa kemampuan berbahasa, sulit bagi manusia untuk berinteraksi antara satu dengan yang lainnya. Me- ngingat pentingnya peranan bahasa sebagai alat komunikasi, maka dunia pendidikan mengadakan pembelajaran bahasa.

Bahasa Indonesia merupakan salah satu materi yang penting dalam 
pembelajaran di sekolah dasar, karena mempunyai kedudukan dan fungsi yang yang sangat penting dalam kehidupan sehari-hari. Pada PP No. 19 Tahun 2005 berdasarkan standar isi, maka kurikulum dan silabus SD atau bentuk lain yang sederajat menekankan pentingnya kemampuan dan kegemaran membaca dan menulis, kecakapan berhitung, serta kemampuan berkomunikasi. Dengan demikian, pembelajaran bahasa pada hakikatnya adalah belajar berkomunikasi melalui empat aspek keterampilan berbahasa yaitu, berbicara, menyimak, membaca, dan menulis,

Menulis merupakan salah satu kompetensi bahasa yang ada dalam setiap jenjang pendidikan, Pada jenjang Sekolah Dasar kelas V, standar pembelajaran menulis adalah siswa mampu mengekspresikan berbagai pikiran, gagasan, pendapat dan perasaan dalam berbagai ragam tulisan melalui menyusun karangan, membuat laporan, menulis surat, meringkas buku bacaan, membuat poster, menulis catatan dalam buku harian serta menulis prosa sederhana dan puisi. Salah satu pembelajaran menulis di kelas V sekolah dasar adalah menulis narasi.

Masalah menulis narasi pada siswa kelas $\mathrm{V}$ menurut hasil penelitian Subandi (2014:2) yaitu siswa mengalami kesulitan dalam menuangkan ide, meruntutkan isi cerita, memadukan kalimat, dan penggunaan ejaan yang kurang tepat. Selain itu, hasil observasi dan wawancara di 4 SDN Kecamatan Sukasari, menunjukkan bahwa siswa kelas V mengalami kesulitan jika diberikan tugas untuk menulis narasi. Hasil skor menulis narasi siswa masih rendah karena memiliki penguasaan kosakata yang rendah, sehingga kalimat dalam tulisan narasi diulang ulang dan siswa belum memperhatikan tanda baca dalam menulis narasi. Hal tersebut dapat dibuktikan dengan perolehan nilai siswa yang belum mencapai Kriteria Ketuntasan Minimal (KKM) yang diharapkan yaitu 75 . Selain itu, peneliti pun masih menemukan pembelajaran yang dilakukan oleh guru monoton dan kurang interaktif dengan teknik yang dilakukan guru yaitu outline melalui drill tanpa media pembelajaran yang bervariasi sehingga siswa cenderung jenuh dan kurang semangat dalam mengikuti pembelajaran dengan tidak adanya motivasi untuk belajar serta siswa kurang antusias dan aktif dalam proses pembelajaran. Oleh karena itu, perlu perbaikan guru dengan menerapkan teknik pembelajaran yang efektif, kreatif dan menyenangkan. Untuk mengatasi hal tersebut, maka peneliti melakukan penelitian dengan menggunakan teknik mind mapping dalam pembelajaran menulis narasi.

Penelitian ini bertujuan untuk mengetahui pengaruh teknik pembelajaran mind mapping terhadap kemampuan menulis narasi siswa. Rumusan masalah dalam penelitian ini adalah; Apakah terdapat pengaruh teknik pembelajaran mind mapping terhadap kemampuan menulis narasi siswa kelas V SDN Kecamatan Sukarasi Kota Bandung?

\section{KAJIAN TEORETIS}

Rusman (2012:95) menjelaskan bahwa kemampuan merupakan "suatu karakteristik umum seseorang yang berhubungan dengan pengetahuan dan keterampilan yang diwujudkan melalui tindakan". Dengan demikian, seseorang yang memiliki kemampuan, akan memudahkannya untuk melaksanakan suatu kegiatan yang diberikan kepadanya dengan didorong adanya motivasi yang tinggi untuk mencapai sesuatu hasil yang maksimum.

Kemampuan menulis tidak akan datang dengan sendirinya tetapi harus melalui latihan dan praktik yang banyak 
dan teratur dan dapat memicu tumbuh kembang daya inisiatif dan kreativitas (Tarigan, 2008:4). Oleh karena itu menulis boleh dikatakan keterampilan yang paling sukar bila dibandingkan dengan keterampilan berbahasa yang lainnya dan menulis memerlukan latihan yang terus menurus secara berkesinambungan supaya mendapatkan hasil yang diharapkan.

Pembelajaran menulis atau mengarang menurut Sunarti dan Subana (2009:231) merupakan keterampilan yang paling sukar bagi siswa jika dibandingkan dengan keterampilan berbahasa lainnya. Oleh karena itu keterampilan menulis cukup mendapatkan perhatian lebih dalam dunia pendidikan. Tarigan (2008:4) menjelaskan bahwa kemampuan menulis tidak akan datang dengan sendirinya tetapi harus melalui latihan dan praktik yang banyak dan teratur dan dapat memicu tumbuh kembang daya inisiatif dan kreativitas. Dengan demikian, kemampuan seseorang diperoleh berdasarkan latihan-latihan yang berkesinambungan sehingga terbiasa dan mampu untuk melaksanakan tugas yang diberikan. Selain itu, Uno (2007:78) menjelaskna bahwa kemampuan adalah karakteristik seseorang dan mengindikasikan cara berperilaku atau berpikir dalam segala situasi yang berlangsung terus menerus dalam periode waktu yang lama. Dengan demikian kemampuan merujuk pada kinerja seseorang dalam melakukan suatu kegiatan.

Kemampuan menulis merupakan salah satu dari empat aspek keterampilan berbahasa. Yunus (2013:1-3) menjelaskan bahwa menulis adalah kegiatan untuk memikirkan, menggali dan mengembangkan suatu ide dan menuangkannya ke dalam bentuk tulisan. Melalui tulisannya, seseorang bisa mengekspresikan ide dan gagasannya secara tertulis untuk dipublikasikan kepada orang lain. Selain itu, menulis adalah salah satu ragam penggunaan bahasa dan kemampuan bahasa yang tercermin dari kemampuan berpikir. Dengan demikian, melatih kemampuan menulis sesungguhnya sama dengan melatih kemampuan berpikir seseorang. Hal ini disebabkan karena kegiatan berpikir individu tersebut dilakukan secara sadar dan tersusun dalam urutan yang berhu-bungan satu dengan yang lainnya sehingga saling berhubungan.

Salah satu pembelajaran menulis kelas V di sekolah dasar yaitu menulis narasi. Finoza (2007:237-238) menjelaskan bahwa narasi (berasal dari narration yaitu bercerita) adalah suatu bentuk tulisan yang berusaha menciptakan, mengisahkan, merangkaikan tindak-tanduk perbuatan manusia dalam sebuah peristiwa secara kronologis atau yang berlangsung dalam suatu kesatuan waktu. Hal ini sesuai dengan pendapat Keraf (1991:136) yang menjelaskan bahwa narasi adalah suatu bentuk wacana yang berusaha menggambarkan dengan sejelas-jelasnya kepada pembaca suatu peristiwa yang telah terjadi dengan menonjolkan unsur perbuatan atau tindakan dalam urutan waktu. Adapun pendapat Rosyadi (2008:72-73) menjelaskan bahwa narasi adalah cerita suatu peristiwa atau kejadian dalam urutan waktu sehingga menimbulkan pengertian yang merefleksikan penulisnya. Dengan demikian, tulisan narasi memperhatikan rangkaian peristiwa atau kejadian cerita dengan kurun waktu tertentu secara kronologis dan membuat pembaca seolah-olah mengalami apa yang dirasakan oleh penulis. Sasaran menulis narasi adalah memberikan gambaran yang sejelas-jelasnya kepada pembaca mengenai fase, urutan, langkah atau rangkaian terjadinya suatu peristiwa atau kejadian. Dengan demikian, narasi merupakan salah satu jenis karangan yang sifatnya bercerita, baik 
berdasarkan pengalaman, pengamatan, maupun berdasarkan rekaan pengarang dengan penulis narasi berharap dapat membawa pembaca kepada suatu suasana yang seperti menyaksikan atau mengalami sendiri peristiwa tersebut.

Akhadiah (1988:2) menjelaskan bahwa menulis harus memperhatikan beberapa kriteria yaitu "isi karangan, aspek-aspek kebahasaan dan teknik penulisan". Dengan demikian, untuk me-nulis harus memperhatikan apa yang akan ditulis, mampu berpikir tepat untuk memilih kata dan juga variasi kalimat yang akan digunakan sehingga tulisannya dapat dipahami pembaca. Selain itu, Akhadiah (1988:2) menjelaskan bahwa menulis sebuah tulisan narasi secara teknis dituntut memenuhi persyaratan dasar dimulai dari "memilih topik, membatasinya, mengembangkan gagasan serta menyajikannya dalam kalimat dan paragraf yang tersusun secara logis dan sebagainya". Supaya tulisan menarik dan enak dibaca maka apa yang dituliskan penulis harus ditata sedemikian rupa sehinga logis, sistematis dan tidak membosankan. Selain itu, untuk "menghasilkan tulisan yang menarik harus memiliki daya inisiatif dan kreativitas yang tinggi" (Yunus, 2013:16). Dalam penelitian ini, kemampuan me-nulis narasi disesuaikan dengan karakteristik sis-wa yaitu menulis narasi ekspositoris.

Djiwandono (2011:122) menjelaskan bahwa rincian kemampuan menulis dalam menentukan tingkat mutu penulisan harus sesuai dengan yang ditugaskan yaitu isi yang relevan, organisasi yang sistematik dan penggunaan bahasa yang baik dan benar. Dimana isi wacana sesuai dengan topik, disusun secara sistematis dan diungkapkan dalam bahasa dengan susunan kalimat yang gramatikal, pilihan kata yang tepat serta intonasi yang sesuai pelafalan yang jelas. Adapun Heaton (1990:135) menjelaskan bahwa dalam menulis harus memperhatikan lima komponen utama yaitu penggunaan bahasa, keterampilan mekanik, isi, keterampilan gaya bahasa dan keterampilan pertimbangan kemampuan untuk menulis dengan cara yang sesuai dalam memilih serta mengatur informasi. Selain itu, Sunarti dan Subana (2009:235) menjelaskan bahwa unsur lain yang dijadikan bahan uji keterampilan menulis antara lain:

1. isi karangan, penilaiannya adalah sejauh mana topik tersebut dapat menjadi masalah menarik yang dapat dipahami oleh pembaca;

2. bentuk karangan;

3. gramatika, perangkat kebahasannya baik dan benar serta sesuai dengan kaidah yang berlaku serta memenuhi sebagai bahasa tulis;

4. gaya penulisan untuk memberikan nada dan warna tertentu terhadap karangan; dan

5. ejaan penggunaan yang tepat memberikan pengaruh yang cukup dalam membangun keutuhan karangan.

Dengan demikian, melalui kemampuan menulis siswa diharapkan mampu menguasai tata bahasa, ejaan, dan tanda baca. Karena kelancaran sebuah komunikasi bergantung pada bahasa yang dikembangkan secara visual.

Berdasarkan teori-teori di atas, maka yang dimaksud dengan kemampuan menulis, narasi dalam penelitian ini adalah kesanggupan untuk menuangkan gagasan dan mengorganisasikan isi gagasan dengan menulis sebuah peristiwa atau kejadian pengalaman sendiri yang disusun secara kronologis sehingga menghasilkan suatu tulisan melalui kalimat yang sesuai dengan kaidah penulisan yang benar, ejaan yang disempurnakan dan pilihan 
kata yang tepat. Aspek penilaiannya yaitu isi gagasan yang dikemukakan meliputi; 1) pengungkapan ide dan 2) kesesuaian judul dengan isi tulisan, organisasi isi karangan meliputi 1) kerangka narasi, 2) kohesi dan koherensi dan 3) kemampuan menyampaikan fakta sehingga pembaca seolah-olah mengalami, penggunaan bahasa meliputi 1) pemakaian struktur kalimat, 2) pilihan kosakata (diksi) dan tata tulisan meliputi ejaan dan tanda baca.

Dalam kegiatan pembelajaran, guru sebaiknya menggunakan teknik yang sesuai dengan materi dan karakteristik siswa supaya pembelajaran bisa tercapai sesuai dengan harapkan. Teknik pembelajaran seringkali disamakan artinya dengan metode pembelajaran. Namun teknik dan metode pembelajaran sangat berbeda. Uno (2007:2) menjelaskan bahwa metode pembelajaran lebih bersifat prosedural yaitu berisi tahapan tertentu sedangkan teknik adalah cara yang digunakan yang bersifat implementatif. Dengan demikian dapat dikatakan guru memilih metode yang sama, namun dengan menggunakan teknik yang berbeda dalam proses pembelajaran.

Teknik pembelajaran menurut Uno dan Nurdian (2012:2) merupakan "jalan, alat atau media yang digunakan oleh guru untuk mengarahkan peserta didik ke arah tujuan yang ingin dicapai". Dengan demikian, istilah teknik pembelajaran mengacu pada berbagai aktivitas yang dilakukan oleh guru dan siswa di dalam kelas dengan selalu direncanakan dan disengaja. Oleh karena itu teknik sangat penting dalam proses pembelajaran berlangsung sehingga tujuan pembelajaran bisa tercapai dengan baik. Dengan demikian, guru harus handal, mampu dalam memilih dan menggunakan teknik dalam proses pembelajaran agar tujuan pembelajaran dapat tercapai sesuai dengan yang direncanakan.

Hardini dan Puspitasari (2012:41) yang menjelaskan bahwa seorang pengajar/guru harus mengetahui dan memahami teknik-teknik penyajian dan sifat-sifat yang khas pada setiap teknik penyajian agar mampu dan terampil meng-gunakannya sesuai dengan tujuan yang hendak dicapai. Oleh karena itu, seorang guru harus terampil dan kreatif dalam mengembangkan teknik pembelajaran yang akan diterapkan dengan memilih strategi yang memberikan peluang bagi siswa untuk terlibat secara aktif dalam proses pencapaian tujuan pembelajaran.

Berdasarkan teori-teori di atas, maka dapat disimpulkan bahwa teknik pembelajaran dalam penelitian ini adalah upaya atau cara yang direncanakan dengan sengaja oleh guru dalam pelaksanaan kegiatan pembelajaran untuk mengembangkan pengetahuan dan keterampilan siswa supaya memperoleh hasil yang optimal dalam rangka mencapai suatu tujuan.

Silberman

(2011:200)

menjelaskan bahwa teknik mind mapping merupakan cara kreatif bagi tiap siswa untuk menghasilkan gagasan, mencatat apa yang dipelajari, atau merencanakan tugas. Dengan menerapkan teknik mind mapping dapat membangkitkan ide-ide orisinal, memicu ingatan yang mudah dan membantu otak berpikir teratur. Selain itu, dengan teknik mind mapping akan membantu siswa dalam mengingat dan mendapatkan ide-ide untuk mengurutkan suatu kejadian atau peristiwa. Dengan adanya interaksi yang luar biasa antara kedua belahan otak tersebut dapat memicu kreativitas yang memberikan kemudahan dalam proses menulis. Sugiarti (dalam Mulyatiningsih, 2011:238) menjelaskan bahwa mind mapping adalah teknik meringkas bahan 
yang perlu dipelajari dan memproyeksikan masalah yang dihadapinya kedalam bentuk peta pikiran atau teknik grafis sehingga lebih mudah memahaminya. Kegiatan ini dapat membantu memahami masalah dengan cepat, karena telah terpetakan dengan bantuan sarana dan prasarana. Selain itu, mind mapping memiliki keuntungan dalam menstimulus anak untuk menghasilkan ide-ide, terlatih memecahkan masalah atau mencari solusi dengan cara berpikir yang simultan dan kreatif, memudahkan untuk berkonsentrasi dan mengatur daya ingatan kerena melibatkan gambar dan warna sehingga akan mendapatkan ide yang brilian untuk mengelompokkan informasi yang diperoleh dalam membentuk tulisan yang menarik.

Prosedur kerja pembuatan mind mapping menurut Buzan (2008:15) adalah sebagai berikut.

1. Mulai dari bagian tengah kertas kosong yang sisi panjangnya diletakkan mendatar. Memulai dari tengah dengan memberi kebebasan kepada otak untuk menyebar kesegala arah dan untuk mengungkapkan dengan lebih bebas dan alami.

2. Gunakan gambar atau foto untuk ide sentral. Sebuah gambar bermakna seribu kata akan membantu untuk berimajinasi dengan sebuah gambar sentral yang menarik, menjadi fokus, melatih untuk lebih konsentrasi.

3. Gunakan warna. Bagi otak, warna sama menariknya dengan gambar. Warna untuk mind mapping lebih hidup, menambah energi untuk berpikir kreatif dan menyenangkan.

4. Hubungkan cabang-cabang utama ke gambar pusat. Bila menghubungkan cabang-cabang, maka akan lebih mudah untuk mengerti dan mengingat. Penghubungan cabangcabang utama akan menciptakan dan menetapkan struktur dasar atau arsitektur pikiran. Ini serupa dengan cara pohon mengaitkan cabangcabangnya yang menyebar dari batang utama.

5. Buat garis hubung yang melengkung, bukan garis lurus. Karena dengan garis lurus akan membosankan anak, cabang-cabang yang melengkung dan organis seperti cabang-cabang pohon jauh lebih menarik bagi mata.

6. Gunakan satu kata kunci setiap garis. Karena dengan kata kunci tunggal memberi lebih banyak daya dan fleksibelitas kepada mind mapp.

7. Gunakan gambar. Seperti gambar sentral, setiap gambar bermakna seribu kata.

Dengan demikian untuk membuat mind mapping diperlukan tujuh langkah dalam penyusunan menulis dengan dimulai dari bagian tengah yang kosong, menggunakan gambar atau foto, warna, menghubungkan cabang-cabang utama ke gambar pusat, membuat garis hubung yang melengkung dan menggunakan satu kata kunci untuk setiap garis dan gambar bermakna dengan seribu kata.

Langkah-langkah mind mapping dalam proses pembelajaran menurut Zaini (2008:168) adalah sebagai berikut:

1. Pilihlah satu masalah topik dan peserta didik melakukan brainstorming (curah gagasan) tentang masalah tersebut

2. Peserta didik memilih konsep-konsep utama dari konsep yang telah ditentukan dengan peserta didik menuliskan konsep-konsep utama

3. Peserta didik mencoba beberapa kali membuat satu gambar dan garis penghubung yang saling berhubungan antar konsep-konsep dengan peserta didik meletakkan konsep yang paling besar di tengah gambar. 
4. Sebelum mengakhiri tugas, peserta didik menulis satu kata atau level di atas setiap garis penghubung.

5. Tampilkan satu peta konsep yang dibuat oleh guru sebagai bahan berbandingan dengan apa yang dikerjakan peserta didik.

6. Mengumpulkan tugas dan mengevaluasi dengan kriteria yang dibuat.

7. Setelah dikoreksi, guru mengembalikannya kepada peserta didik.

Berdasarkan teori-teori di atas, maka yang dimaksud teknik mind mapping dalam penelitian ini adalah suatu cara memetakan sebuah informasi yang digambarkan kedalam bentuk cabang-cabang pikiran dengan bantuan simbol, gambar dan warna serta diungkapkannya melalui sebuah tulisan yang kreatif dalam menulis narasi dengan langkah-langkah sebagai berikut yaitu: 1) Guru dan peserta didik bersama-sama memilih tema dan siswa menuliskannya di kertas kosong dengan peserta didik bersama-sama mendiskusikannya; 2) Guru menyediakan media gambar/foto dan peserta didik menempelkannya pada kertas kosong; 3) Siswa mengamati gambar yang disediakan guru dan guru membuat kata kunci dari gambar tersebut; 4) Guru memandu siswa untuk me-nyusun sebuah kejadian atau peristiwa pe-ngalaman sendiri secara kronologis dengan siswa membuat ranting-ranting pikiran; 5) Siswa diminta untuk mengembangkan ide baru dengan menambahkan ranting yang sudah ada; dan 6) ranting-ranting pikiran yang sudah dibuat siswa dikembangkan menjadi sebuah tulisan narasi.

Teknik konvensional dalam penelitian ini menggunakan outline melalui drill. Outline menurut Langan (2008:35) merupakan pusat menulis paragraf yang baik yang dapat membantu untuk berpikir jernih dan logis dengan merencanakan sebuah kertas yang terorganisasi dengan baik. Dengan demikian, outline dalam menulis sangat diperlukan dan sangat membantu dalam menuangkan gagasan yang akan disampaikan kepada pembaca sehingga tulisan menjadi sistematis. Hal ini sesuai dengan pendapat Hs Widjono (2012:324) yang menjelaskan bahwa outline merupakan rangkaian ide yang dapat disusun secara sis-tematis, logis, jelas dengan format yang terstruktur. Selain itu Akhadiah (1988:25) menjelaskan bahwa outline merupakan suatu rencana kerja yang mengandung ketentuan-ketentuan tentang bagaimana menyusun suatu rangkaian ide yang jelas secara terstruktur dan logis. Adapun Finoza (2007:217) yang menjelaskan bahwa kerangka karangan (outline) dapat mengalami perubahan yang terus menerus untuk mencapai bentuk yang sempurna dan bentuk kerangka karangan berupa catatan sederhana te-tapi dapat juga mendetail dengan bentuk tulisan yang linier. Oleh karena itu, dalam pembuatan outline akan mengalami perubahan yang disesuaikan dengan kebutuhan penulisnya dan memudahkan seorang penulis untuk mengembangakan ide dan pikirannya dengan penulisan dimulai dari atas ke bawah atau dari kiri ke kanan dengan tulisan yang sistematis.

Fungsi teknik outline menurut $\mathrm{Hs}$ Widjono (2012:324-325) yaitu memperlihatkan pokok bahasan dan memberi kemungkinan perluasan bahasan sehingga memungkinkan penulis menciptakan suasana kreatif sesuai dengan variasi yang diinginkan, mencegah pembahasan keluar dari sasaran yang sudah dirumuskan, memudahkan penulis menyusun karangan secara menyeluruh dan mencegah pengulangan ide. Dengan demikian, teknik outline digunakan untuk mengatur ide yang mencakup ide 
utama yang disusun secara sistematis dan teratur untuk mempermudah dalam menulis.

Teknik outline dalam penelitian ini melalui drill yang di ulang-ulang. Hardini dan Puspitasari (2012:44) menjelaskan bahwa penyajian latihan (drill) memberi kesempatan kepada siswa untuk melakukan kegiatan latihan agar memiliki keterampilan yang lebih tinggi dari apa yang dipelajari. Latihan dimaksudkan untuk membantu siswa dalam belajar dengan mengembangkan kemahiran dan keterampilannya sehingga siswa terampil dalam melakukan suatu tugas yang dibebankan kepadanya. Selain itu, Langan (2008:35) menjelaskan bahwa "melalui latihan akan membantu dalam mengembangkan kemampuan garis besar dan menulis sebuah paragraf'. Hal ini disebabkan karena melalui latihan (drill) siswa akan dapat memperoleh suatu ketangkasan dari apa yang telah dipelajari olehnya.

K Roestiyah

(2008:125)

menjelaskan bahwa keterampilan siswa dalam latihan adalah kecakapan fisik seperti kecakapan gerak, menulis, menggunakan alat, olahraga dan kecakapan asosiasi misalnya menghubungkan antara satu keadaan dengan keadaan lain. Dengan melaksanakan kegiatan latihan secara praktis dan teratur, siswa lebih terampil dan berprestasi dalam bidang tertentu, terutama bila digunakan dalam pelajaran bahasa. Misalnya pelafalan, intonasi dan lain sebagainya. Adapun Mulyatiningsih (2011:240) menjelaskan bahwa drill digunakan ketika peserta didik disuruh mengulang informasi pada topik-topik khusus sampai peserta didik me-nguasai topik yang diajarkan. Dengan demikian diperlukan pengulangan yang terus menerus supaya siswa mengerti dan paham mengenai pembahasan materi yang sedang diajarakan guru.

Thoifuri (2008:68) mengatakan bahwa kelebihan drill ini di antaranya, siswa dapat menguasai keterampilan yang diharapkan sehingga ia mempunyai pengetahuan siap guna dan akan tertanam kebiasaan belajar secara rutin dan disiplin. Kelemahanya diantaranya bisa menghambat perkembangan daya inisiatif siswa serta membentuk kebiasaan tidak fleksibel. Adapun pendapat K. Roestiyah (2008:127) yang menjelaskan bahwa suatu latihan yang dijalankan dengan cara tertentu yang telah dianggap baik dan tepat, sehingga tidak boleh berubah dalam pembelajarannya mengakibatkan keterampilan yang diperoleh oleh siswa pada umumnya juga menetap/pasti dan membuat kebiasaan yang kaku. Oleh karena itu, bila situasi berubah siswa sukar sekali menyesuaikan diri atau tidak bisa mengubah cara latihanmya untuk mengatasi keadaan yang lain. Adapun kadang-kadang latihan dijalankan tanpa penjelasan sebelumnya berakibat tidak terjadi pemahaman, sehingga siswa melakukan apa yang ditugaskan tanpa maksud dan tujuan latihan tersebut.

Berdasarkan teori-teori di atas, maka yang dimaksud dengan teknik konvensional dalam penelitian ini adalah penerapan kerangka karangan (outline) secara berulang-ulang sehingga siswa dapat mengembangkan kerangka karangannya untuk menulis narasi dengan format tulisan dari atas ke bawah atau dari kiri ke kanan. Adapun langkahlangkah teknik outline melalui drill yaitu, 1) Guru memberikan teks kepada siswa dan siswa dibantu untuk bersamasama meng-analisis kerangka karangan (outline) dari setiap paragraf; 2) Guru memberikan tema dan siswa disuruh membuat kerangka karangan (outline) secara kronologis dari tema yang 
ditentukan oleh guru; dan 3) Guru membuat kerangka karangan (outline) dan siswa menulis narasi dari kerangka karangan (outline) yang dibuat oleh guru.

\section{METODE PENELITIAN}

Metode yang digunakan dalam penelitian ini adalah metode eksperimen. Sugiyono (2013 : 109) menjelaskan bahwa metode eksperimen yaitu "metode penelitian yang digunakan untuk mencari pengaruh perlakuan tertentu terhadap yang lain dalam kondisi yang terkendalikan". Metode yang digunakan dalam penelitian ini adalah metode eksperimen dengan model two group post-test design. Penelitian ini dilakukan untuk mengetahui pengaruh teknik pembelajaran mind mapping ter-hadap kemampuan menulis narasi.

Riduwan (2006:54) menjelaskan bahwa populasi adalah keseluruhan dari karakteristik atau unit hasil pengukuran yang menjadi objek penelitian. Populasi dalam penelitian ini adalah seluruh SDN di Kecamatan Sukasari Bandung kelas V Tahun tahun ajaran 2013/2014. Selain itu, Riduwan (2006:56) menjelaskan bahwa sampel merupakan bagian dari populasi yang mempunyai ciri-ciri atau keadaan tertentu yang akan diteliti. Pengambilan sampel yang digunakan da-lam penelitian ini adalah purposive sampling. Sampel yang diambil adalah SD Negeri Sukarasa 4 dengan alas an di SD ini kemampuan menulis siswa lebih rendah dibandingkan dengan SD yang lain.

Penelitian ini menggunakan quasi experiment (eksperimen semu) dengan dua kelompok, yaitu kelas eksperimen dan kelas kontrol. Kelas eksperimen mendapat perlakuan menggunakan teknik pembelajaran mind mapping (A1) sedang-kan kelas kontrol dengan teknik konvensional (A2) yaitu outline melalui drill. Instrumen ke-mampuan menulis narasi dalam penelitian ini adalah narasi ekspositoris dengan menggunakan tes tertulis berbentuk essay yang dibuat oleh sis-wa.

Teknik analisis data dalam penelitian ini adalah menyusun data post-test, menghitung nilai rata-rata dari variabel hasil post-test, menghitung standar deviasi, menghitung uji normalitas, uji homogenitas, dan menghitung uji hipotesis.

\section{HASIL DAN PEMBAHASAN}

Rata-rata kemampuan menulis narasi dengan menggunakan teknik pembelajaran mind mapping adalah 81,95 dengan standar deviasi sebesar 8,58 dari jumlah siswa sebanyak 20 orang. Nilai tertinggi pada teknik mind mapping adalah 92 dan nilai terendah 68. Uji normalitas kelas eksperimen dengan uji lilierfos diproleh $\mathrm{L}_{\text {hitung }}=$ 0,1180 . Dengan demikian $\mathrm{L}_{\text {hitung }}<\mathrm{L}_{\text {tabel }}$ $(0,1180<0,190)$, maka dapat dikatakan bahwa distribusinya normal. Sedangkan rata-rata kemampuan menulis narasi di kelas kontrol dengan menggunakan teknik outline melalui drill adalah 76,2 dengan standar deviasi sebesar 5,47 dari jumlah siswa sebanyak 20 orang. Nilai tertinggi pada teknik outline melalui drill adalah 86 dan nilai terendah 67 . Uji normalitas dengan uji lilierfos diperoleh $\mathrm{L}_{\text {hitung }}=0,1706$. Dengan demikian $\mathrm{L}_{\text {hitung }}$ $<\mathrm{L}_{\text {tabel }}(0,1706<0,190)$, maka dapat dikatakan bahwa distribusinya normal.

Dari hasil penelitian menunjukkan bahwa rata-rata kemampuan menulis narasi siswa yang belajar menggunakan teknik mind mapping (A1) lebih tinggi atau lebih baik daripada nilai rata-rata kemampuan menulis narasi siswa yang belajar dengan teknik outline melalui drill (A2). Berikut nilai rata rata dari hasil kemampuan menulis narasi siswa. 


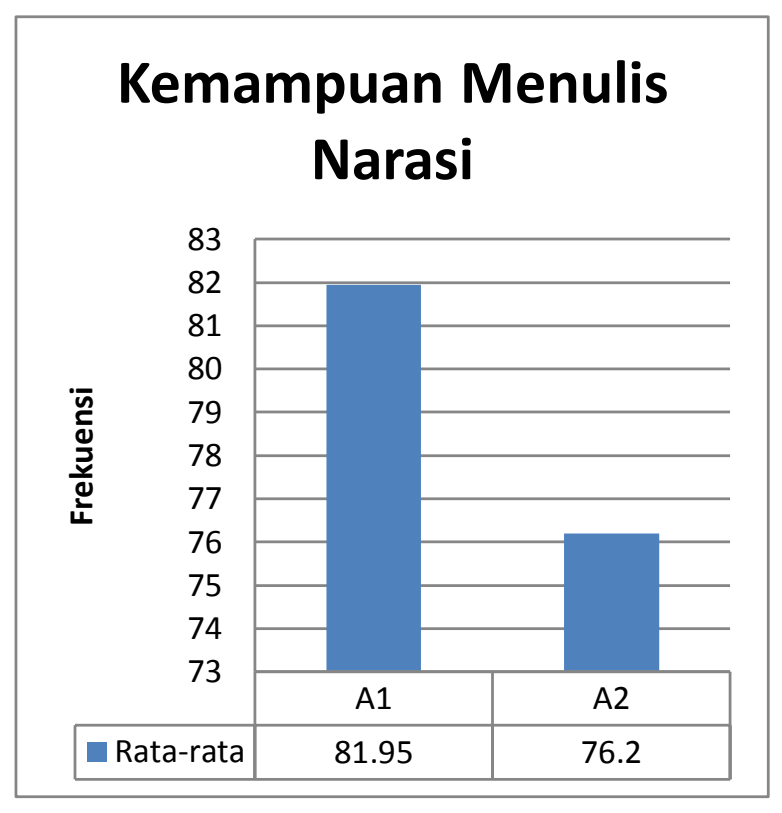

\section{Gambar 3.1. \\ Rekapitulasi Hasil Kemampuan Menulis Narasi}

Hasil penelitian menunjukkan bahwa $t_{\text {hitung }}>t_{\text {tabel }}$ pada taraf signifikan $0,05(95 \%)$ dengan ketentuan apabila $\mathrm{t}_{\text {hitung }}$ lebih besar dari $\mathrm{t}_{\text {tabel }}$ yakni 2,527 > 1,729 berarti Ho ditolak sebaliknya $\mathrm{Ha}$ diterima. Dengan demikian, teknik pembelajaran mind mapping berpengaruh terhadap kemampuan menulis narasi siswa kelas V SDN 4 Sukarasa Kota Bandung Tahun 2014.

Hasil tulisan narasi siswa yang belajar dengan teknik mind mapping yaitu pengungkapan gagasan jelas, logis, mudah dipahami dan sesuai dengan tema serta disusun secara kronologis serta cerita berakhir dengan jelas. Adanya peningkatan kemampuan menulis narasi siswa yang belajar dengan teknik mind mapping dikarenakan siswa dapat memvisualisasikan jalan pikirannya melalui pemanfaatan otak kiri dan kanannya dengan tema sentral yang dikelilingi oleh gambar, pikiran, pola, kata-kata dan ide kreatif dengan ide penunjang.
Interaksi yang luar biasa di antara kedua belahan otak dapat memicu kreativitas siswa yang memberikan kemudahan dalam proses mengingat dan berpikir dengan menggunakan gambar, warna dan simbol. Terbiasanya siswa dengan menggunakan dan mengembangkan potensi kedua otaknya, maka akan dicapai peningkatan beberapa aspek yaitu berimajinasi, konsentrasi, kreativitas dan meningkatkan daya ingat sehingga siswa dapat mengambil keputusan berkualitas dalam menuangkan gagasannya ke dalam tulisan.

Penelitian ini sejalan dengan penelitian Maknun (2013:111) yang menyatakan bahwa bahwa penggunaan teknik mind mapping dalam pembelajaran menulis narasi dapat meningkatkan hasil belajar menulis narasi. Oleh karena itu, teknik mind mapping sangat baik diterapkan untuk meningkatkan kemampuan menulis narasi siswa. Adapun Wahyuni (2012: 137) yang membuktikan bahwa kelompok siswa yang belajar dengan menggunakan mind mapping lebih tinggi daripada peserta didik yang belajar dengan menggunakan teknik outline melalui drill dalam pembelajaran menulis eksposisi. Selain itu, penelitian Nurromadani (2013:55) menjelaskan bahwa terjadi peningkatan keterampilan menulis narasi dengan metode peta pikiran (mind mapping). Pendapat lain yaitu Warseno dan Kumorojati (2011:83) yang menjelaskan bahwa adanya peningkatan kemampuan menulis narasi siswa yang belajar dengan menggunakan teknik mind mapping. Hal ini dicapai karena teknik pembelajaran mind mapping mengajarkan siswa untuk melihat persoalan dengan media gambar dan cabang-cabang pikiran secara keseluruhan serta melihat hubungan satu sama lain sehingga hasil menulisnya runtut dan terpadu. 
Pada teknik konvensional yaitu outline melalui drill, siswa belajar secara berulang ulang dalam pembuatan outline untuk menulis narasi dengan tulisan dari atas ke bawah atau dari kiri ke kanan serta tidak menggunakan gambar. Dengan demikian pada teknik outline melalui drill, siswa hanya menggunakan otak kiri, serta siswa merasa jenuh dan bosan dalam proses pembelajaran. Syah (2010:162) berpendapat bila peserta didik sudah dalam keadaan bosan atau jenuh, sistem akalnya tidak dapat bekerja sebagaimana yang diharapkan dan kecakapan yang diperoleh dari belajar tidak ada kemajuan. Oleh karena itu, hal tersebut akan menimbulkan efek negatif bagi kemampuan menulis narasi siswa. Hasil tulisan narasi siswa yang belajar dengan teknik pembelajaran outline melalui drill yaitu siswa menulis narasi dengan pengungkapan gagasan kurang atau tidak jelas, alur berpikirnya kurang logis, tidak memuat latar belakang karangan yang ingin disampaikan, ide pokok dan ide penunjang kurang lengkap dengan tidak menampilkan kreativitas serta penyampaian fakta tidak mengakibatkan pembaca seolah olah mengalami apa yang diarasakan penulis.

Dengan demikian, berdasarkan hasil temu-an penelitian dan kajian teori, dapat disimpulkan bahwa teknik mind mapping lebih lebih efektif diterapkan dalam membantu meningkatkan kemampuan menulis narasi siswa.

\section{SIMPULAN}

Berdasarkan hasil analisis data dan perhitungan statistik, maka dalam penelitian ini diperoleh simpulan yaitu rata-rata kemampuan menulis narasi siswa dengan menggunakan teknik pembelajaran mind mapping yaitu 81,95, sedang-kan rata-rata kemampuan menulis narasi siswa yang belajar dengan menggunakan teknik outline melalui drill yaitu 76,2. Hasil pengujian hipotesis menunjukkan bahwa $t_{0}>t_{\text {tabel }}$ $(2,527>1,729)$. Dengan demikian, teknik pembelajaran mind mapping berpengaruh terhadap kemampuan menulis narasi siswa kelas V SDN 4 Sukarasa Kota Bandung Tahun 2014. Hal ini disebabkan karena, pada teknik mind mapping, siswa belajar dengan memvisualisasikan ide dan gagasannya ke dalam cabang pikiran dengan menggunakan gambar dan warna yang dapat memudahkan siswa untuk mengingat dan menuangkannnya kedalam tulisan narasi. Oleh karena itu, hasil pembelajaran menulis narasi dengan menggunakan teknik pembelajaran mind mapping lebih berpengaruh terhadap kemampuan menulis narasi daripada hasil pembelajaran menulis narasi dengan menggunakan teknik pembelajaran konvensional (outline melalui drill).

Berdasarkan kesimpulan, diajukan beberapa saran yang dapat dipertimbangkan dalam peningkatan kemampuan menulis narasi siswa yaitu: (1) untuk meningkatkan hasil belajar yang maksimal, disarankan kepada guru untuk menggunakan teknik mind mapping sehingga siswa termotivasi dan senang dalam pembelajaran menulis narasi; (2) guru sebaiknya mendapatkan pengalaman dan mengetahui faktor-faktor apa saja yang dapat mempengaruhi kemampuan menulis narasi siswa sebelum menginterpretasikannya kedalam pelajaran menulis narasi; (3) guru yang belum memahami pembelajaran dengan menggunakan teknik mind mapping diharapkan dapat meningkatkan pengetahuannya melalui pelatihan-pelatihan; dan (4) bagi peneliti lain disarakan mengadakan pene-litian sejenis dengan sampel yang lebih banyak yang terdiri dari beberapa sekolah untuk melihat seberapa besar konstribusi teknik pembelajaran terhadap kemampuan menulis narasi siswa. 
DAFTAR PUSTAKA

Akhadiah, Sabarti, Maidar G. Arsjad dan Sakura Ridwan.(1988). Pembinaan kemampuan menulis bahasa Indonesia. Jakarta: Erlangga.

Buzan, Tony. (2008). Buku pintar mind map. Jakarta: Gramedia Pustaka Utama.

Djiwandono, Soenardi. (2011). Tes bahasa pegangan bagi pengajar bahasa. Malang: Indeks.

Finoza, Lamudin. (2007). Komposisi bahasa Indonesia untuk mahasiswa nonjurusan bahasa. Jakarta: Diksi Insan Mulia.

Hardini, Isriani dan Puspitasari, Dewi. (2012). Strategi pembelajaran terpadu (teori, konsep \& implementasi. Yogyakarta: Familia.

Heaton, J.B. (1990). Writing english language tests new edition consultans editor jeremy harmer and roy kingsbury. United States America.

Hs, Widjono (2012). Bahasa Indonesia mata kuliah pengembangan kepribadian di perguruan tinggi edisi revisi ke 2. Jakarta: Grasindo.

Keraf, Gorys. (1991). Argumentasi dan narasi. Jakarta: Gramedia Pustaka Utama.

K, Roestiyah N. (2008). Strategi belajar mengajar. Jakarta: Rineka Cipta.

Langan, Jhon. (2008). Exploring writing para-grafhs and essays. America: McGrawHill Higher Education.

Maknun, Lu'luil. (2013). Peningkatan hasil belajar menulis narasi bahasa Indonesia melalui teknik mind mapping. Jakarta: Tesis Pasca Sarjana UNJ.

Mulyatiningsih, Endang. (2011). Metode penelitian terapan bidang pendidikan. Bandung: Alfabeta.

Nurromadani. (2013). Peningkatan keterampilan menulis narasi dengan metode peta pikiran (mind mapping) pada siswa kelas iv mi yaspuri malang. Jurnal pendidikan, 1 (2). Hal.55.Tersedia:https://badriyadi.files.wordpress.c om. (Diambil tanggal 22 Juni 2014).

PP No.19 Tahun 2005 tentang Standar Nasional Pendidikan, Pasal 6, ayat 6 .

Riduwan. (2006). Belajar mudah penelitian untuk guru dan karyawan dan peneliti pemula. Bandung: ALFABETA.

Rosyadi, Rahmat. (2008). Menjadi penulis profesional itu mudah. Jakarta: Ghalia Indonesia.

Rusman, (2012). Model-model pembelajaran mengembangkan profesionalisme guru edisi kedua. Jakarta: GrafindoPersada.

Silberman, Melvin L. (2011). Active learning: 101 cara belajar siswa aktif (cetakan ke-4). Bandung: Nusamedia.

Subana dan Sunarti, Subana. (2009). Strategi belajar mengajar bahasa Indonesia. Bandung: Pustaka Setia.

Subandi, Ahmad Utman, Hari Satrijono, Suhartiningsih. (2014). Meningkatkan kemampuan menulis karangan narasi sugestif dengan menggunakan media gambar seri siswa kelas $v$ sdn arjasa 02 jember tahun pelajaran 2012/2013. Jurnal edukasi unej, $i$ (1). Hal.2. Tersedia:http://jurnal.unej.ac.id/index.php/JEUJ/article/ view/1024/821. (Diambil tanggal 18 Mei 2014).

Sugiyono. (2013). Metode penelitian kombinasi (mixed methods). Bandung: Alfabeta.

Syah, Muhibbin. (2010). Psikologi pendidikan dengan pendekatan baru. Bandung: Remaja Rosda Karya. 
Tarigan, Henry Guntur. (2008). Menulis sebagai suatu keterampialn berbahasa. Bandung: Angkasa Bandung.

Thoifuri. (2008). Menjadi guru inisiator. Se-marang: Rasail Media Group.

Uno, Hamzah. (2007). Model pembelajaran, menciptakan proses belajar mengajar yang kreatif dan efektif. Jakarta: Bumi Aksara.

Uno, Hamzah B dan Nurdian, Mohamad. (2012). Belajar dengan pendekatan paikem: pembelajaran aktif, inovatif, lingkungan kreatif, efektif, menarik. Jakarta : Bumi Aksara.

Wahyuni, Desli. (2012). Pengaruh strategi belajar kognisi dan penalaran terhadap kemampuan menulis eksposisi (studi eksperimen di smkn 11 jakarta barat). Jakarta: Tesis Pasca Sarjana UNJ.

Warseno, agus dan kumorojati, ratih. (2011). Super learning praktis belajar mengajar yang serba efektif dan mencerdaskan. Yogyakarta: DIVA Press.

Yunus dkk. (2013). Keterampilan menulis. Tangerang Selatan: Universitas Terbuka.

Zaini, Hisyam. Bermawy Munthe, dan

Sekar Ayu Aryani. (2008).

Strategi pembelajaran aktif.

Yogyakarta: Pustaka Insan

Madani. 